\title{
Author Correction: Impaired mitophagy links mitochondrial disease to epithelial stress in methylmalonyl-CoA mutase deficiency
}

\author{
Alessandro Luciani, Anke Schumann, Marine Berquez, Zhiyong Chen (D), Daniela Nieri, Mario Failli, \\ Huguette Debaix, Beatrice Paola Festa, Natsuko Tokonami, Andrea Raimondi @ , Alessio Cremonesi, \\ Diego Carrella, Patrick Forny (1D, Stefan Kölker, Francesca Diomedi Camassei, Francisca Diaz, Carlos T. Moraes, \\ Diego Di Bernardo (D), Matthias R. Baumgartner (D) \& Olivier Devuyst (D)
}

Correction to: Nature Communications https://doi.org/10.1038/s41467-020-14729-8, published online 20 February 2020.

The original version of this Article contained an error in Fig. 3g, in which the text under the right bracket read "14 dpf-HP fed zebrafish", when it should have read "14-dpf". This has been corrected in both the PDF and HTML versions of the article.

Published online: 01 April 2020

\begin{abstract}
(c) (i) Open Access This article is licensed under a Creative Commons Attribution 4.0 International License, which permits use, sharing, adaptation, distribution and reproduction in any medium or format, as long as you give appropriate credit to the original author(s) and the source, provide a link to the Creative Commons license, and indicate if changes were made. The images or other third party material in this article are included in the article's Creative Commons license, unless indicated otherwise in a credit line to the material. If material is not included in the article's Creative Commons license and your intended use is not permitted by statutory regulation or exceeds the permitted use, you will need to obtain permission directly from the copyright holder. To view a copy of this license, visit http://creativecommons.org/licenses/by/4.0/.
\end{abstract}

(C) The Author(s) 2020 